\title{
Is policy paralysis on quarantine issues in the Near East and North Africa region leading to the buildup and spread of red palm weevil, Rhynchophorus ferrugineus?
}

\author{
Sarath B. Balijepalli ${ }^{1}$ and J.R. Faleiro ${ }^{2}$ \\ (1) ICAR - National Bureau of Plant Genetic Resources, Rajendranagar, Hyderabad 500030, Telangana State, India, \\ email: Sarath.Balijepalli@icar.gov.in; (2) Food and Agriculture Organization of the United Nations, Goa, India
}

\begin{abstract}
Balijepalli, S.B. and J.R. Faleiro. 2019. Is policy paralysis on quarantine issues in the Near East and North Africa region leading to the buildup and spread of red palm weevil, Rhynchophorus ferrugineus?. Arab Journal of Plant Protection, 37(2): 89-100.

The red palm weevil (RPW) is now a global threat, demanding a global strategy for its control and eventual eradication. In North Africa, RPW has been reported from all the countries except Algeria leaving several queries as to why this pest did not reach there. Enforcement of strict quarantine measures in the five Maghreb countries of Algeria, Morocco, Tunisia, Libya and Mauritania kept the weevil at bay until 2008, but the region is today riddled with this dreaded pest with the exception of Algeria. There is plenty of evidence to suggest that strict regulatory regimes can restrict the spread and eventually eradicate the pest. The RPW-IPM program of Canary Islands in Spain where the RPW was effectively eradicated with no reports of weevil captures since 2016 is a classic example. Likewise, in Mauritania and Morocco quarantine laws did prevent the spread of the weevil, restricting it to the original foci of infestation. Ineffective quarantine regimes coupled with weak enforcement and difficulties in early detection of infested plants contributed to the rapid spread of RPW. Country reports on variety of issues right from the status, challenges and recommendations with respect to RPW control in Egypt, Iran, Iraq, Libya, Morocco, Mauritania, Oman, Palestine, Qatar, Saudi Arabia, Tunisia and Yemen reveal that the weevil arrived in these countries through infested date palm offshoots, ornamental palms or hitch hiking on moving vehicles. Although quarantine laws/decrees/ordinances existed in most countries to prevent the movement of plants however, ineffective and poor enforcement and implementation has resulted in the rapid spread of the pest which can be attributed to policy paralysis. Focus must therefore be shifted to devising mechanisms for effective decision making in implementing phytosanitary regulations to stop the spread of RPW both within national borders and also across international boundaries. Based on recent experiences in Saudi Arabia, recommendations drafted during the last mission in 2018 on phytosanitation and quarantine protocols for the Kingdom are presented here that could serve as guidelines on quarantine issues against RPW for the region. Specific regulations and measures are sought to be developed with in the phytosanitary legislation especially with regard to palm tree inspections, removal of infested palms, movement of palms and treatment protocols. Enforcement of harmonized plant quarantine protocols for phytosanitary treatments and specifications of planting material produced through certified palm nurseries on the basis of IPPC standards (ISPM 36) besides establishment of tissue culture laboratories with standard production protocols to facilitate RPW free planting material throughout the region are presented in this article.
\end{abstract}

Keywords: Rhynchophorus ferrugineus, red palm weevil, quarantine protocols, phytosanitation, policy regulations, policy paralysis, NENA, registered nurseries, certified offshoots, tissue culture plants.

\section{Introduction}

The red palm weevil (RPW), Rhynchophorus ferrugineus (Olivier) (Coleoptera: Curculionidae) is a key pest of palms originating from South and South East Asian Countries that has significantly expanded its geographical and host range during the last three decades. In the Near East, RPW is causing wide spread damage to date palm, Phoenix dactylifera $\mathrm{L}$., having both agricultural impacts on the palm production, which has negative repercussions on the livelihoods of farmers and environmental impacts. In North Africa, except in Algeria, RPW is spreading its tentacles very fast though few years ago it was only thriving in few limited spots, only on the Canary Island palm $P$. canariensis. Even when these spots are located on the Mediterranean coast, they represent a serious threat for the Southern oasis.

RPW destroys palm trees by eating them from the inside, invaded rapidly from South East Asia in to more than 60 countries during the last three decades. It threatens date and coconut palms, as well as ornamentals. Factors contributing to the spread have been lack of healthy certified planting material, late detection of infested palms because of insufficient inspections, lack of engagement with date and coconut farmers, improper assessment of the risks, ineffective natural enemies of the pest, difficulties in managing mass trappings across large oases networks, lax quarantine, improper disposal of infested trees, and the difficulty in controlling the pest in private homes or small family gardens. All over the NENA region and other Mediterranean countries, IPPC standards, policy regulations and legislations are either not functioning with harmony or there are no proper enforcing mechanisms in some countries culminating into spread of this insect to dangerous proportions. There is an overall policy paralysis, calling for attention of the decision makers for policy formulation and enforcement in some regions afresh and its activation wherever it is sluggish on priority in NENA region (Figure 1). In a nutshell, the RPW in the recent past turned to a global threat demanding a global strategy to eradicate it, as declared by FAO Director-General José Graziano da Silva in a recent strategic scientific consultative meeting to combat the RPW menace. The message emanating from the scientific 
consultative meeting is a positive one: The Red Palm Weevil can be controlled and defeated.

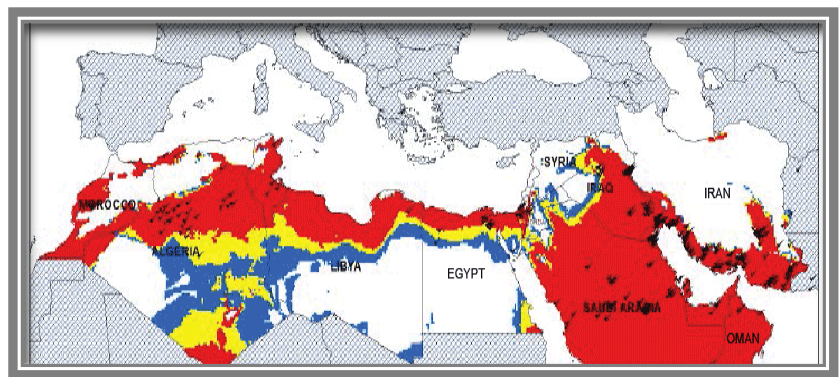

Figure 1. Red palm weevil conquering most territories of the Near East and North African region

Abraham et al. (1998) highlighted the importance of implementing strict quarantine regimes as a component of the $R$. ferrugineus control strategy. Transport of date palm offshoots for date farming and bigger date palms for landscape gardening often resulted in this cryptic pest moving rapidly to new regions or also in and around plantations where the pest is already controlled, resulting in new foci of $R$. ferrugineus. Experiences from the Gulf region in the Middle-East and the Mediterranean countries have shown that RPW had spread rapidly through infested planting material transported mainly for ornamental purposes and also date palm farming (Faleiro et al., 2012). Several date palm producing countries have legal decrees restricting/banning the movement of such material. Very often implementing the decree becomes difficult especially due to the lack of quarantine protocols for treatment of offshoots/palms and subsequent certification of the material as "pest-free". In Europe the palm nursery industry is strictly regulated to supervise the movement of palms (EPPO 2008). In Saudi Arabia, Al-Shawaf et al. (2013) developed a quarantine protocol of dipping date palm offshoots in $0.004 \%$ Fipronil for 30 minutes to destroy all stages of the pest. Consultation in the form of national and regional cooperation among date producing countries is essential to deploy and implement uniform quarantine regimes to control this key pest of date palm in the entire NENA region.

Systematic approach to deal with this pest yielded success, as in case of the Canary Islands. The pest was detected in 2005 and caused destruction of thousands of canary palm during the following years. A systematic policy declaration and enforcement with very strict vigil brought down the insect pressure tremendously by 2015 and the islands were declared RPW free by May 2016 (Fajardo, 2017). Implementing a coordinated strategy that included tight monitoring controls, healthy planting material and the removal of all infested trees. In Mauritania, detection of the pest in an oasis triggered quick action by the Government with the support of FAO to implement an integrated pest management strategy that had farmers and farmer cooperatives at the core. The pest has been successfully contained to the original infestation area, without any outbreaks from May 2016.

The new framework (RPW Expert Team, 2017) aims to provide technical assistance and guidance for improving national control programs as well as a platform for interregional cooperation and coordination. It was produced by an international team of Red Palm Weevil experts from various countries and organizations with the support of FAO, CIHEAM and the Near East Plant Protection Organization (NEPPO) (FAO, 2017).

Just four palm species were affected by red palm weevil when studies were done in 1956, but now the pest attacks 40 palm species worldwide (Malumphy and Moran, 2009). The three most-affected species today are coconut palm, date palm and the tall ornamental Canary Island date palm.

\section{Global Economic and Social Impact of RPW Infestations}

The weevil, which has spread rapidly through the Middle East and North Africa in the last three decades, causes economic losses in millions of dollars annually through lost production and pest control. It attacks 40 palm species, the most affected being the coconut palm, date palm and the tall ornamental Canary Island date palm (Gibbins-Davis et al., 2013).

Date palm represents a symbol of life in the Near East and North Africa (NENA) region and has a long heritage of sustaining human life in hot and infertile areas, where it is seen as a renewable natural resource. RPW has significant socio-economic impact on the date palm production sector and livelihoods of farmers in affected areas. In the MiddleEast, RPW has been the most destructive insect pest of date palm and is designated as category- 1 pest by FAO. The annual loss during 2009 in the Gulf region of the MiddleEast due to removal of severely infested palms has been estimated to range from 1.74 to 8.69 million USD at 1 and $5 \%$ infestation, respectively. Recent reports indicate that in the Mediterranean region, palms worth up to 483 million Euros have been destroyed or infested, primarily by RPW. However, this figure remains a significant underestimate of the total economic value of affected palms because no study has accounted for all of the ecosystem services they provide. In the Spanish region of Murcia over 7 million Euros were spent on various measures to combat RPW mainly on the removal of infested palms. Between 2004 and 2009, in the autonomous community of Valencia around 20,000 palms, mostly Phoenix canariensis, were killed by RPW, where losses were estimated to be 16 million Euro (Faleiro et al., 2012)

In recent years, $R$. ferrugineus has been the most destructive insect of palm plantations throughout the world (Bertone et al., 2010), and FAO has designated it as category-1 pest on date palm in the Middle-East. Losses in global production of dates have been estimated at 30\% due to the plant diseases and pests (FAOstat, 2013). The annual loss in the Gulf region of the Middle-East due to eradication of severely infested palms has been estimated to range from US\$1.74 to 8.69 million at 1 and 5\% infestation, respectively (El-Sabea et al., 2009). 


\section{Red Palm Weevil Invasion}

In a recent global conference, FAO head Jose Graziano da Silva said, "The red palm weevil has become a global threat and demands a global strategy to eradicate it." Agricultural ministers have agreed on a plan to fight the red palm weevil which ravages coconut, date and oil palms, experts said describing it as "a global threat". The red weevil, which has few natural enemies, has spread to more than 60 countries from the Caribbean to southern Europe, according to FAO which hosted a meeting of scientists, pest control experts, farmer representatives and government officials in Rome (RPW Expert Team, 2017).

Red palm weevil literally conquered the date palms in the Middle-Eastern and the Mediterranean region since 1985, its occurrence as a pest was reported from Ras-AlKhaima in UAE (Zaid et al., 2002), where it probably got introduced through infested planting material (ornamental palms) from South/South East Asia. Red palm weevil in Saudi Arabia, was first detected in an ornamental nursery in Al Qatif in early 1987, from where it spread to the entire Kingdom through date palm offshoots and also through bigger palms transported for ornamental purposes (Anonymous, 1998; RPW Red palm weevil website). It crossed the red sea in early 1990's and was recorded in Egypt in 1992 and in Spain in 1995 (Barranco et al., 1996; Cox, 1993). The entire Mediterranean basin is currently reporting RPW infestations mostly on Phoenix canariensis (Faleiro, 2006 and OJEU, 2008) (Table 1). Previous experiences suggest that shipments of ornamental palms without quarantine certification have contributed significantly to the spread of RPW (Faleiro, 2006 and Oehlschlager, 1994). The Maghreb region of North Africa is critically situated between several RPW infested countries including Egypt on the East, the Canary Islands on the West and European countries including Spain, Portugal, France and Italy in the North (RPW, Red Palm Weevil, http://www.redpalmweevil.com/). This region has around 12 million date palms in the susceptible age group of less than 20 years (Table 1) and several avenue plantings/nurseries of $P$. canariensis offering RPW an ideal agro-climatic zone to establish and spread in the region. It is relevant to point out that during 2 years (2008-2010), RPW was recorded in the Maghreb region (Tangier in Northern Morocco and Libya) (RPW, Red Palm Weevil, http://www.redpalmweevil.com/), the American continent (Dutch Antilles Island in the Caribbean), Laguna Beach area of Orange County, California, USA and Eastern Europe (Georgia) (RPW, Red Palm Weevil, http://www.redpalmweevil.com/). With regard to the Orange County report, lack of response by the weevil to the pheromone (ferrugineol) traps and limited spread of the weevil in the Laguna Beach area suggest that it may not be Rhynchophorus ferrugineus. However, all these reports are attributed to palms maintained (garden nurseries) or shipped for ornamental purposes. Reports from area-wide RPW-IPM programme in KSA indicated that $75 \%$ of the infested date palms are in the age group of 6 to 15 years (Anonymous, 1998; Oehlschlager, 1994). This is the age group of palms preferred for ornamental landscaping purposes as stated in the first report of RPW in the Caribbean Island of Curacao
(Dutch Antilles) when date palms imported from Egypt for ornamental purposes (RPW First Report in the Caribbean ; RPW, Red Palm Weevil, http://www.redpalmweevil.com/). It is evident that the initial source of infestation occurred in most of the countries through imports of palms for ornamental purposes which subsequently spread to date palm plantations (RPW, Red Palm Weevil, http://www.redpalmweevil.com/). Therefore, the Maghreb countries should impose a ban on the imports and regulate internal movement of palms for ornamental gardening. The pest was accidentally introduced into the territory of the European Union. Spain reported its presence in 1996 and this was followed by reports from Italy in 2004, Greece in 2005, Cyprus and France in 2006, Malta and Portugal in 2007, and Slovenia in 2009. Currently it is present in all Mediterranean Member States and Portugal (Faleiro et al., 2012).

The Maghreb region of North Africa successfully avoided invasion by red palm weevil until 2008, when it was confirmed to be present in Morocco (Faleiro et al., 2012). Its presence was subsequently confirmed in Libya in 2009 (AlEryan et al., 2010), and in Dec 2011, despite laws established several decades earlier strictly forbidding the importation of live palms (EPPO 1999), red palm weevil was confirmed for the first time in Tunisia, in Carthage Township, Tunis (Chebbi, 2011). (Rugman-Jones et al., 2017) reported invasion of Tunisian palms by RPW. Moreover, although red palm weevil is currently restricted to urban areas in Tunis, its establishment poses a major socio-economic threat to the date industry in the southern regions of the country. Tunisia is the biggest supplier of dates to the European Union (BenAmor et al., 2015), and it is estimated that $\sim 12 \%$ of Tunisians derive income from date production (Faleiro et al., 2012). Although the RPW is reported from all over the Meghreb region of North Africa, it was not found in any of the official records in Algeria (Faleiro, 2012), and absence of RPW through surveys in Algeria was confirmed by datasheet records (CABI, 2018). Therefore, it is worth studying the case of Algeria and its regulations systematically. Quarantine measures or strict regulations through decrees were undertaken in Algeria strictly to eradicate the Bayoud disease (Nadia Bouguedoura, 2015) within the region. In early 1970s three million palms in Algeria and 10 million in Morocco were lost due to Bayoud disese caused by Fusarium oxysporum f. sp. albedinis (Foa) Malençon Snyd and Hans (Malençon, 1934). Strict policy enforcement by the Algerian government on movement of planting material to arrest the spread of Bayoud along with usage of tissue culture plants promoted by FAO both in Morocco and Algeria (Bouguedoura, 2015). Although RPW is a serious pest all around in Meghreb countries the weevil is yet to be reported from Algeria which is confirmed by CABI (Faleiro et al., 2012; CABI, 2018; EPPO, 2014)

Outside the NENA region, the RPW appearance in Caucasus is also very alarming. It is very alarming to learn that during 2011-2017 an unusually high number of invasive pests new to European Russia were detected for the first time in Sochi on the Black Sea coast of the Caucasus (Bieńkowski et al., 2018). The Caucasus is a region located between the Black and Caspian Seas. It consists of Southern Russia, Georgia, Armenia, and Azerbaijan. Known for its alpine terrain, the Caucasus is home to Mount Elbrus, the highest 
mountain peak in Europe, located on the Russo-Georgian border.

RPW, native to South-East Asia, began to spread in the 1980s outside its native range and now this invasive species has been established in the Middle East, North Africa, North America, countries of the Caribbean and South Europe (EPPO, 2017). It was added to the EPPO A2 list in 2006 and is regarded as a quarantine pest in several countries (EPPO, 2017). In 2009 R. ferrugineus was found in the Caucasus for the first time in Georgia (Pelikh, 2009). In 2012-2013 it was recorded in Sochi, where it mainly damages Phoenix canariensis and Washingtonia robusta (Karpun et al., 2014).

\section{Phytosanitary and Quarantine Regulations in NENA Region}

Quarantine regulations in NENA region have been either non serious or policy protocols non-existent or were not enforced strictly based on international standards like IPPC. With the movement of planting material of dates and adult palms of ornamental palms freely across the borders in the NENA regions, the RPW moved without any quarantine challenge resulting in widespread distribution of the pest. RPW is a quarantine pest in the Near East and North Africa (NENA) countries, as well as in countries in Latin America, where it is the object of emergency measures in the European Union, and is considered a quarantine pest that should be regulated in EPPO countries as it is considered of limited distribution (A2 pest). Weak quarantine procedures and difficulties in the early detection of RPW-infested plant materials have contributed to its rapid spread. RPW has been spreading globally and has not been effectively managed in spite of several efforts and resources provided by countries and organizations. Extensive research has also been conducted on the management of RPW (RPW Expert Team, 2017).

With the advent of plant genetic resources collection, conservation and utilization, legal and regulatory phytosanitary systems have been developed in accordance with international directives and standards to regulate germplasm movement, exchange and quarantine of planting material, especially of clonally propagated fruit trees such as date palm (Noreiga et al., 2012). As anticipated, the germplasm movement and exchange would accelerate as countries in the southern hemisphere were establishing large scale date palm plantations. The large volume of international germplasm transfer coupled with recent rapid advances in biotechnology called for development of date palm specific regulations for its phytosanitary safety during transfer and movement across the globe. The slow pace of policy development and the policy enforcement together could be defined as a policy paralysis which happened in the NENA region resulting in the spread of the invasive RPW pest. Therefore, even today, careful planning and enforcement of strategies designed for the arrest and spread of RPW across the NENA region would go a longway in reducing further spread and eventually eradicating the dreaded date palm enemy (RPW Expert Team, 2017).

Table 1. Red palm weevil appearance and spread in NENA region

\begin{tabular}{|c|c|c|}
\hline Country & Year of Infestation & Reference \\
\hline United Arab Emirates & 1985 & Zaid et al., 2002 \\
\hline Qatar & 1985 & Zaid et al., 2002 \\
\hline Kingdom of Saudi Arabia & 1987 & Oehlschlager, 1994 \\
\hline Iran & 1990 & RPW, Red Palm Weevil, http://www.redpalmweevil.com/ \\
\hline Kuwait/Behrain & $1988-1993$ & RPW, Red Palm Weevil, http://www.redpalmweevil.com/ \\
\hline Egypt & 1992 & Cox, 1993 \\
\hline Jordan/Israel/Palestine & 1999 & Kehat, 1999 \\
\hline Spain & 1995 & Barranco et al., 1996 \\
\hline Canary Islands & 2006 & EPPO, 2008 \\
\hline Greece & 2005 & $\begin{array}{l}\text { EPPO Reporting Service, } 2006 \\
\text { RPW, Red Palm Weevil, http://www.redpalmweevil.com/ }\end{array}$ \\
\hline France & 2006 & EPPO Reporting Service, 2006 \\
\hline Turkey & 2005 & RPW, Red Palm Weevil, http://www.redpalmweevil.com/ \\
\hline Malta & 2007 & Department of Plant Health, 2010 \\
\hline Cyprus & 2006 & RPW, Red Palm Weevil, http://www.redpalmweevil.com/ \\
\hline Morocco & 2008 & $\begin{array}{l}\text { EPPO, } 2010 \\
\text { RPW, Red Palm Weevil, http://www.redpalmweevil.com/ }\end{array}$ \\
\hline Georgia & 2009 & RPW, Red Palm Weevil, http://www.redpalmweevil.com/ \\
\hline Portugal & 2006 & $\begin{array}{l}\text { RPW, Red Palm Weevil, http://www.redpalmweevil.com/ } \\
\text { http://www.aambiental.org/palmweevil/ }\end{array}$ \\
\hline Libya & 2009 & RPW, Red Palm Weevil, http://www.redpalmweevil.com/ \\
\hline Tunisia & 2011 & Chebbi, 2011; EPPO, 2011 \\
\hline
\end{tabular}




\section{Benchmark Global Programmes}

The author of this article having worked as quarantine expert for FAO, worked out and recommended in March 2018, a systematic approach including an incentive based phytosanitary regime for KSA. As a team player in the cluster of experts to combat RPW, long term strategies were drawn out for effective future management of RPW in the kingdom.

The benchmarks have been set up while dealing with the invasive species in countries like Saudi Arabia, Canary Islands, Mauritania, Morocco, Oman, Morocco and others (Table 2). These benchmarks and some good agricultural practices have been assessed for better understanding of the successful programmes and for adoption in KSA (Balijepalli, 2018a).

Looking at the variety of situations in the context of SPS of WTO viz., the European Union, the situation in Near East and North Africa is reviewed in this report in order to analyze and study the relevance and applicability of certain situations and provisions for adoptability with respect to the Kingdom of Saudi Arabia. There are specific examples such as Canary Islands, where a strong programme with adequate resources, systematic planning, good coordination and the involvement of all stakeholders, which lead to the control and eradication of RPW. In Mauritania, a swift reaction by the national authorities involving farmers and local communities, with the support of FAO, has also led to the rapid containment of the pest (RPW Expert Team, 2013).

\section{Sanitary and Phytosanitary Measures}

We need to understand SPS of WTO in the backdrop of international exchange of germplasm and commercial movement of agricultural commodities. This has immediate ramifications with respect to arresting or regulating the global movement of harmful pathogens and pests along with the food commodities. The WTO Agreement on Sanitary and Phytosanitary measures encourages member countries to use international standards, guidelines and recommendations where they exist. Members of the WTO can also use measures which result in higher standards, if there is scientific justification. They can also set higher standards based on appropriate assessment of risks so long as the approach is consistent and not arbitrary. Sanitary and phytosanitary measures aim to protect animal or plant life or health within the territory of the member country from risks arising from the entry, establishment or spread of pests, diseases and disease-causing organisms.

Within the policy framework and phytosanitary regulatory measures, FAO of the UN has in its Crop Production and Protection Division (AGP), a Transboundary Pests and Diseases Unit and Integrated Pest Management (IPM) Unit, for providing assured and quality technical assistance to member countries in areas associated with plant health. In addition, FAO hosts the secretariats of the international conventions and Commissions related to plant protection and pest management as the International Plant Protection Convention (IPPC) and its Commission on phytosanitary measures (CPM), which is the global treaty for the international harmonization of phytosanitary measures. IPPC is the organization that actually sets the standards in plant protection, quarantine and phytosanitary protocols based on regulations of planting material or agricultural commodities both for commercial and research exchange purposes for the benefit of all member countries of WTO. Therefore, the protocols required for pest risk analysis (PRA), establishment of certified nurseries, declaration of regulated non-quarantine pest, establishment of areas of low pest prevalence in the context of RPW are relevant. These very standards need to be applied towards developing policies and sui generis legislation in member countries for developing policy and regulations in quarantine and phytosanitation.

Saudi Arabia is a member of the World Organization for Animal Health (OIE), the Codex Alimentarius Commission, and a contracting party to the International Plant Protection Convention (IPPC). With regard to animals, plants, and their products, SPS measures are harmonized at the GCC level under the Veterinary Quarantine Law and the Plant Quarantine Law, and the corresponding Executive Regulations provide details of their implementation in Saudi Arabia. Saudi Arabia maintains bilateral arrangements on SPS matters with Belgium, Brazil, Canada, Denmark, Djibouti, Ethiopia, France, India, Ireland, the Netherlands, Kenya, Pakistan, Sudan, Turkey, the United Arab Emirates (Abu Dhabi), and the United States.

\section{The Situation in European Union}

The main legislative framework of the plant health regime in the EU is Council Directive 2000/29/EC of 8 May 2000 on protective measures against the introduction into the Community of organisms harmful to plants or plant products and against their spread within the Community (European Commission, 2011).

Red palm weevil situation in European Union is by and large under check with the necessary amendments to the legislation and policy framework in 2007 and 2010. The RPW menace was successfully eradicated in areas like the Archipelago of Canary Islands where concerted efforts and systematic approach supported by the needful policy and legislation declared the island as completely free from the red palm weevil. The island of Gojo in Malta is now considered free of this organism. Also in Koper (the region of Slovania), the reports of few palms being infested and the successive efforts resulted in positively as there was no recurrence of the RPW since 2010.

The weevil having spread its tentacles in most palm growing areas has been on rampage with several countries like Cyprus, Greece, France, Italy, Malta, Portugal, Slovenia and Spain on record having initiated the fight against the spread of the weevil but without major success of eradication so far (Balijepalli, 2018a)

\section{The Policy Adopted in European Union}

It is quite relevant to highlight some of the European Union situations and protocols governing palm trade in Europe in the light of RPW menace in the Mediterranean basin 
countries that could be studied, modified and adopted to suit the needs of Kingdom of Saudi Arabia. RPW was added in 2005 to the EPPO A2 action list and endangered EPPO member countries are advised to regulate it as a quarantine pest. The RPW in European Union has been by and large successful in checking the spread culminating into large scale destruction of palms. As dwelled in the mission report (Balijepalli, 2018a), the policy interventions included mainly the following measures:

1. Delimitation of survey and demarcated areas

2. Three monthly official inspections

3. Annual crop declarations

4. Application of phytosanitary treatments

5. Registration of planting material movements

6. Use of plant passport to the trade of palms

The emergency measures, whenever red palm weevil strikes, include:

1. Categorisation of the red palm weevil: Rhynchophorus ferrugineus (Olivier).

2. Listing of susceptible hosts: 23 species and one genus of palms.

3. Specific requirements for the imports into the EU

4. Specific requirements for the internal movements within the EU.

5. Surveys to check for the presence or continued absence of red palm weevil.

6. Demarcation of areas in the community where red palm weevil is present.

\section{Recommended Incentive-based Phytosanitary Regime for KSA}

The mission undertaken by the quarantine experts recommended an incentive based phytosanitary regime in the Kingdom to deal with the RPW (Balijepalli, 2018a). The model developed for KSA which is incentive-based, especially with respect to making the healthy planting material available to the farmers, has been included and dealt with extensively (Table 3). The prerequisite studies for establishing the registered nurseries to supply certified planting material under the IPPC regime and its standards have been defined and protocols developed. The challenges identified and the policy paralysis existing throughout the NENA region have been discussed in the international meeting (Balijepalli, 2018b). There are some grey areas of crucial importance with respect to establishing demonstration farms to produce certified palm seedlings like identification of pest free areas (PFAs) and areas of low pest prevalence (ALPPs) etc. These are very significant in order to provide sources for offshoots or tissue culture plants to be further grown and developed under the supervision of trained inspectors and the inspection system, before supplying them to farmers. All this has to be undertaken following the best of standards established by IPPC (ISPM 36).

Significant contributions from the said mission are summarized as follows:

1. Assessing current internal quarantine system for palm seedlings and designed an improved system.
2. Working out an appropriate regulatory framework and incentives for certified palm seedlings. A protocol has been prepared on the basis of IPPC standard (ISPM 36) for implementation in the kingdom.

3. Support selection of appropriate mix of technologies for prevention and control of RPW insect based on benchmarking and good international practices.

4. Designed an integrated methodology for prevention and control of red palm weevil insect and its implementation in a pilot area.

5. Selection of a pilot area for testing and implementation of the strategy based on variety of technical and administrative inputs as team player.

The recommended crucial tasks or need to be undertaken in due course of time are:

1. Establishing demonstration farms that produce certified palm seedlings.

2. Train farmers and technicians and extension agents in selected technologies and practices.

3. Support training of farmers, technicians and extension agents in selected technologies and practices.

4. Legislative interventions with respect to amendments to quarantine law especially the incentives for compliance to regulations and to create sense of awareness of enforcement of regulations and punitive actions for violation by various stake holders.

5. All the partially undertaken or unfulfilled tasks are somewhere or the other related to the establishment of registered nurseries to produce certified date palm offshoots.

During this mission strategy for the production of certified offshoots has been developed. Also, necessary protocol for the production of certified offshoots has been developed to be synchronized with the planting material output from the tissue culture laboratories. The protocol broadly consists of the following.

a) Estimation of annual offshoot requirement in the kingdom.

b) Estimation of planting material already being produced by tissue culture.

c) Synchronization of activities of offshoot sourcing from recognized farms and sourcing of tissue culture plants based on scientific principles and established phytosanitary measures in accordance with the IPPC standards.

d) Protocols for sourcing, production, movement and distribution of offshoots / planting material in accordance with the IPPC (ISPM 36) standards.

e) Identifying pest free areas (ISPM 4) for sourcing offshoots and nursery establishment to produce certified offshoots.

f) Identifying areas of low pest prevalence and finding large farms (ISPM 22) for sourcing offshoots and nursery establishment to produce certified offshoots.

g) Finally establishing the demonstration farms as well as the nurseries producing certified date palm offshoots.

h) Training all stakeholders in the ministry, the internal quarantine team to carry out the necessary inspection and measures to ensure pest free offshoots and the 
identified nursery owners on protocols and phytosanitary requirements.

i) Also a campaign to build awareness among the farmers to recognize the necessity of using only certified offshoots in the interest of the kingdom to get rid of the menace of red palm weevil.

Table 2. Bench Marking and Success criteria

\begin{tabular}{|c|c|c|c|c|c|}
\hline Key Components & $\begin{array}{c}\text { Saudi Arabia } \\
\text { (Country report } \\
\text { FAO })\end{array}$ & $\begin{array}{c}\text { Canary Islands } \\
\text { (government } \\
\text { source) }\end{array}$ & $\begin{array}{c}\text { Morocco } \\
\text { (Country report } \\
\text { FAO) }\end{array}$ & $\begin{array}{l}\text { Oman, } 2015 \\
\text { (Country } \\
\text { report) }\end{array}$ & Israel \\
\hline $\begin{array}{l}\text { Survey } \& \text { infestation and } \\
\text { number of palms in the } \\
\text { area reports }\end{array}$ & $\begin{array}{l}\text { Available from the } \\
\text { year } 1987 \text { when first } \\
\text { detected and number } \\
\text { of palms known }\end{array}$ & $\begin{array}{l}\text { Comprehensive } \\
\text { data available from } \\
2005 \\
\text { Eradicated in } 2016\end{array}$ & $\begin{array}{l}\text { Detected for the first } \\
\text { time in Morocco in } \\
\text { December } 2008 \text { in } \\
\text { Tangiers }\end{array}$ & $\begin{array}{l}\text { First reported } \\
\text { in } 1993\end{array}$ & $\begin{array}{l}\text { First reported in } \\
1999 \text { and from } \\
2000 \text { to } 2002 \text { IPM } \\
\text { was imposed in } \\
\text { Jordan valley }\end{array}$ \\
\hline $\begin{array}{l}\text { what are the preventive } \\
\text { measures/practices put in } \\
\text { place to control RPW in } \\
\text { the county }\end{array}$ & $\begin{array}{l}\text { 1. Inspection and } \\
\text { treatment of palm } \\
\text { injuries } \\
\text { 2. No use of irrigation } \\
\text { water on palm trunks. } \\
\text { 3. Farmers' } \\
\text { cooperation in good } \\
\text { agricultural practices }\end{array}$ & $\begin{array}{l}\text { Prohibition of } \\
\text { susceptible palms } \\
\text { less than } 5 \mathrm{~cm} \\
\text { diameter. } \\
\text { Two preventive } \\
\text { treatments a year }\end{array}$ & $\begin{array}{l}\text { Preventive } \\
\text { chemical, } \\
\text { Pheromone trapping } \\
\text { were by NPPO. } \\
\text { Also removal of old } \\
\text { palms }\end{array}$ & $\begin{array}{l}\text { Management } \\
\text { practices were } \\
\text { effectively } \\
\text { enforced. }\end{array}$ & $\begin{array}{l}\text { Prophylactic } \\
\text { insecticide and } \\
\text { pheromone traps. } \\
\text { Acoustic detectors } \\
\text { and trained dogs } \\
\text { used for detecting } \\
\text { early }\end{array}$ \\
\hline $\begin{array}{l}\text { what extent are } \\
\text { preventive measures/ } \\
\text { practices applied by } \\
\text { farmers/ stakeholders to } \\
\text { control }\end{array}$ & $\begin{array}{l}30 \% \text { of the farmers } \\
\text { and stockholders }\end{array}$ & $100 \%$ & $\begin{array}{l}\text { Farmers applied } \\
\text { curative measures. }\end{array}$ & $\begin{array}{l}65 \% \text { of the } \\
\text { farmers and } \\
\text { stakeholders }\end{array}$ & \\
\hline $\begin{array}{l}\text { plant } \\
\text { quarantine(phytosanitary) } \\
\text { measures and regulations }\end{array}$ & $\begin{array}{l}\text { Saudi Arabia bans the } \\
\text { trading, } \\
\text { transportation, import } \\
\text { and export all kinds of } \\
\text { date palms in infested } \\
\text { areas applying the } \\
\text { statutory procedures }\end{array}$ & $\begin{array}{l}\text { Importers of palms } \\
\text { much register with } \\
\text { Directorate } \\
\text { General. Permits } \\
\text { required for plant } \\
\text { movement }\end{array}$ & $\begin{array}{l}\text { Import of adult palm } \\
\text { trees banned in } \\
2007 . \text { Orders in } \\
\text { place } 2009 \text { control } \\
\text { and surveillance }\end{array}$ & $\begin{array}{l}\text { Royal decrees } \\
\text { issued in } \\
2009 \text {, prohibit } \\
\text { import and } \\
\text { internal } \\
\text { movement of } \\
\text { host }\end{array}$ & $\begin{array}{l}\text { Import of palms } \\
\text { prohibited (1970). } \\
\text { Stringent } \\
\text { quarantine } \\
\text { regulations are } \\
\text { applied. No } \\
\text { movement of } \\
\text { offshoots }\end{array}$ \\
\hline $\begin{array}{l}\text { What are the } \\
\text { challenges/constrains } \\
\text { facing the application of } \\
\text { quarantine measures? }\end{array}$ & $\begin{array}{l}\text { Lack of awareness } \\
\text { about the importance } \\
\text { of Quarantine } \\
\text { measures. } \\
\text { Lack of commitment } \\
\text { to implement } \\
\text { Quarantine law }\end{array}$ & $\begin{array}{l}\text { Quarantine applied } \\
\text { strictly. RPW was } \\
\text { eradicated from the } \\
\text { Islands }\end{array}$ & $\begin{array}{l}\text { Preventive control } \\
\text { applied in areas } \\
\text { where infested } \\
\text { palms detected. } \\
\text { Very costly }\end{array}$ & $\begin{array}{l}\text { Awareness } \\
\text { about the pest } \\
\text { is not } \\
\text { available }\end{array}$ & \\
\hline $\begin{array}{l}\text { Are the location of traps } \\
\text { and the number of } \\
\text { captured RPW known } \\
\text { precisely and frequently } \\
\text { up- to- date }\end{array}$ & $\begin{array}{l}\text { The location of traps } \\
\text { and the number of } \\
\text { captured RPW is } \\
\text { recorded }\end{array}$ & $\begin{array}{l}\text { GIS used. Trap and } \\
\text { Weevil capture data } \\
\text { collected. }\end{array}$ & $\begin{array}{l}\text { Traps are checked } \\
\text { every week. Data } \\
\text { are computerized }\end{array}$ & $\begin{array}{l}\text { Mass trapping } \\
\text { is applied and } \\
\text { data available }\end{array}$ & $\begin{array}{l}\text { Mass trapping with } \\
\text { pheromone traps } \\
\text { done in Jordan } \\
\text { valley }\end{array}$ \\
\hline $\begin{array}{l}\text { Are the data used as a } \\
\text { tool for decision support } \\
\text { regarding the activities? }\end{array}$ & $\begin{array}{l}\text { Data are used as a } \\
\text { tool for decision } \\
\text { support regarding the } \\
\text { activities }\end{array}$ & Yes. & Yes & $\begin{array}{l}\text { Yes. They are } \\
\text { used for } \\
\text { decision } \\
\text { making }\end{array}$ & Yes \\
\hline $\begin{array}{l}\text { What is the source of } \\
\text { offshoots to farmers? Are } \\
\text { they controlled by the } \\
\text { plant protection services } \\
\text { and how? } \\
\text { Certified nurseries }\end{array}$ & $\begin{array}{l}\text { Offshoots is available } \\
\text { through coordination } \\
\text { between farmer and } \\
\text { directorate of } \\
\text { agriculture } \\
\text { Certified nurseries are } \\
\text { Tissues culture palms }\end{array}$ & $\begin{array}{l}\text { Accredited } \\
\text { nurseries are } \\
\text { sources of plants. } \\
\text { Certified nurseries } \\
\text { available. }\end{array}$ & $\begin{array}{l}\text { There are regular } \\
\text { nurseries and tissue } \\
\text { culture nurseries }\end{array}$ & $\begin{array}{l}\text { There are no } \\
\text { certified } \\
\text { nurseries in } \\
\text { the country. } \\
\text { Source of } \\
\text { offshoots are } \\
\text { other farmers }\end{array}$ & \\
\hline $\begin{array}{l}\text { What are the constrains } \\
\text { facing the early } \\
\text { detection? }\end{array}$ & $\begin{array}{l}\text { Lack of special device } \\
\text { to detect the RPW } \\
\text { infection in the early } \\
\text { stages }\end{array}$ & $\begin{array}{l}\text { All infested palms } \\
\text { were eradicated. }\end{array}$ & $\begin{array}{l}\text { Difficulty of early } \\
\text { detection }\end{array}$ & $\begin{array}{l}\text { No } \\
\text { technology } \\
\text { and } \\
\text { awareness, } \\
\text { poor } \\
\text { agronomic }\end{array}$ & \\
\hline
\end{tabular}


Table 2. Cont...

\begin{tabular}{|c|c|c|c|c|c|}
\hline Key Components & $\begin{array}{c}\text { Saudi Arabia } \\
\text { (Country report } \\
\text { FAO) } \\
\end{array}$ & $\begin{array}{c}\text { Canary Islands } \\
\text { (government } \\
\text { source) }\end{array}$ & $\begin{array}{c}\text { Morocco } \\
\text { (Country report } \\
\text { FAO })\end{array}$ & $\begin{array}{l}\text { Oman, } 2015 \\
\text { (Country } \\
\text { report) }\end{array}$ & Israel \\
\hline $\begin{array}{l}\text { What are the challenges/ } \\
\text { constrains facing the } \\
\text { management practices? }\end{array}$ & $\begin{array}{l}\text { Non-application of } \\
\text { the unified } \\
\text { mechanism. } \\
\text { Difficult of } \\
\text { geography. } \\
\text { Human and financial. } \\
\text { No biological control }\end{array}$ & $\begin{array}{l}\text { Project successfully } \\
\text { completed. }\end{array}$ & $\begin{array}{l}\text { High level and } \\
\text { continuous team } \\
\text { mobilization; } \\
\text { High costs for } \\
\text { control }\end{array}$ & $\begin{array}{l}\text { Geographical } \\
\text { distribution of } \\
\text { palms. Labor } \\
\text { cost. Absence } \\
\text { of biocontrol }\end{array}$ & $\begin{array}{l}\text { High cost of } \\
\text { pheromone } \\
\text { trapping. Not } \\
\text { sustainable in large } \\
\text { areas }\end{array}$ \\
\hline $\begin{array}{l}\text { What is the role of the } \\
\text { Government in } \\
\text { supporting the farmers in } \\
\text { management of RPW? }\end{array}$ & $\begin{array}{l}\text { Doing all the } \\
\text { prevention and } \\
\text { control operations }\end{array}$ & $\begin{array}{l}\text { Full support of the } \\
\text { government. Passed } \\
\text { legislation at the } \\
\text { island level }\end{array}$ & $\begin{array}{l}\text { Government } \\
\text { through ONSSA is } \\
\text { doing control } \\
\text { operations \& giving } \\
\text { materials } \\
\end{array}$ & $\begin{array}{l}\text { Government } \\
\text { supports } \\
100 \% \text { in } \\
\text { management } \\
\text { of RPW. }\end{array}$ & $\begin{array}{l}\text { Plant protection \& } \\
\text { Inspection } \\
\text { services, Ministry } \\
\text { of Agriculture }\end{array}$ \\
\hline $\begin{array}{l}\text { what is the role of the } \\
\text { extension services in the } \\
\text { country }\end{array}$ & Yes, to some extent & & $\begin{array}{l}\text { Extension agents } \\
\text { were trained by } \\
\text { FAO and ONSSA } \\
\end{array}$ & & \\
\hline $\begin{array}{l}\text { Have participatory } \\
\text { approach and methods } \\
\text { been used to implicate } \\
\text { the farmers? }\end{array}$ & Yes & $\begin{array}{l}\text { Participatory } \\
\text { approach followed }\end{array}$ & $\begin{array}{l}\text { Training and } \\
\text { awareness raising } \\
\text { workshops with all } \\
\text { stakeholders/farmers } \\
\text { even in areas that } \\
\text { are not infested }\end{array}$ & & \\
\hline $\begin{array}{l}\text { Are incentive and } \\
\text { dissuasive (including } \\
\text { fines) been used to } \\
\text { improve the farmers } \\
\text { cooperation }\end{array}$ & $\begin{array}{l}\text { There are no incentive } \\
\text { and dissuasive. }\end{array}$ & No & $\begin{array}{l}\text { Control is } \\
\text { mandatory. Garden } \\
\text { owners comply }\end{array}$ & & \\
\hline $\begin{array}{l}\text { List any other major } \\
\text { challenges or constrains } \\
\text { that make the RPW } \\
\text { management difficult or } \\
\text { un successful? }\end{array}$ & $\begin{array}{l}\text { Lack of adequate } \\
\text { financial and human } \\
\text { resources. } \\
\text { Lack of awareness } \\
\text { among some farmers } \\
\text { and officials. } \\
\text { Lack of training }\end{array}$ & $\begin{array}{l}\text { The project was } \\
\text { completed and the } \\
\text { area was declared } \\
\text { RPW free in May } \\
2016 .\end{array}$ & $\begin{array}{l}\text { Intensive } \\
\text { surveillance and } \\
\text { control is } \\
\text { challenging } \\
\text { physically for } \\
\text { workers and } \\
\text { financially costly }\end{array}$ & & \\
\hline
\end{tabular}

Table 3. Benchmarks for adoption by the Kingdom of Saudi Arabia

\begin{tabular}{|c|c|c|c|}
\hline S. No & Bench Mark & $\begin{array}{l}\text { Country setting the } \\
\text { Bench Mark }\end{array}$ & Challenge for KSA \\
\hline 1. & $\begin{array}{l}\text { Prohibition of off shoots with more than } 5 \\
\mathrm{~cm} \text { diameter }\end{array}$ & Canary Islands & $\begin{array}{l}\text { Moving away from } 6 \mathrm{~cm} \text { diameter to } 5 \mathrm{~cm} \\
\text { offshoots } \\
\text { Strictly enforcing two treatments a year }\end{array}$ \\
\hline 2. & $\begin{array}{l}\text { Preventive control applied quickly where } \\
\text { RPW appeared on priority }\end{array}$ & Morocco & KSA should take up \\
\hline 3. & $\begin{array}{l}\text { Government support in amending the law } \\
\text { and promulgating regulations }\end{array}$ & $\begin{array}{l}\text { Canary Islands } 100 \text { per cent } \\
\text { Oman } 100 \text { per cent }\end{array}$ & KSA must amend the legislation \\
\hline 4. & Two preventive treatments a year & Canary Island & Should be enforced \\
\hline 5. & Early Detection using acoustics and dogs & Others & Should be considered \\
\hline 6. & Prophylactic treatments & Others (very imp) & Should be enforced \\
\hline 7. & $\begin{array}{l}\text { Accredited nurseries are sources of plants. } \\
\text { Certified nurseries available }\end{array}$ & Canary Islands & $\begin{array}{l}\text { KSA must initiate certification of nurseries for } \\
\text { accreditation }\end{array}$ \\
\hline 8. & Tissue culture nurseries to be allowed & Oman & Tissue culture nurseries to be allowed \\
\hline 9. & $\begin{array}{l}\text { Training of Extension agents, Farmers and } \\
\text { other stakeholders }\end{array}$ & Canary Islands & KSA to take up \\
\hline 10. & $\begin{array}{l}\text { Successful Eradication of RPW with strict } \\
\text { enforcement and excellent coordination } \\
\text { among the stakeholders }\end{array}$ & Canary Islands & $\begin{array}{l}\text { KSA to build coordination and efforts for } \\
\text { enforcement of rules and protocols }\end{array}$ \\
\hline
\end{tabular}


As a member of the cluster in the given period of time, the timeline for developing the date palm quarantine system has been put on track during this mission with the following activities scheduled:

- The standalone internal quarantine regulation for the red palm weevil and the strategy to work out pest risk analysis (PRA) for regulated non quarantine pests (RNQP) worked out in accordance with ISPM 21 and ISPM 16, the IPPC standards respectively. As a pre requisite the existing GCC plant quarantine law has been studied thoroughly along with the decree that banned the import of all kinds of palms in to the kingdom. The status of presence of red palm weevil has to be viewed comprehensively as we gear up to consider the weevil as the RNQP and the PRA to that extent in order to exercise the sovereign rights of the kingdom to continue regulation of palm imports.

- Also the strategy to work out for the establishment of strong phytosanitary system which includes developing protocols for removal, shredding and disposal of infested palms along with other farm level phytosanitary measures, has been put in place.

-A significant and crucial quarantine measure viz., developing appropriate regulatory and incentive measures for production, distribution and use of healthy date palm offshoots (planting material) has been developed and included in the set of recommendations for the Kingdom.

- Once the mechanism of suggested protocols are scrutinized for harmony with other components of integrated strategy including the protocols for the production of tissue culture planting material are ready, demonstration farms that produce certified palm seedlings could be developed in association with the MEWA officials and the other ministries. A pilot programme for the control of red palm weevil in the designated area would eventually find momentum for implementation.

\section{The Way Forward}

The current extent of the RPW impact on palm trees is a consequence of the inadvertent movement of cryptically infested plants across different regions and countries. Therefore, the effective control of its ongoing expansion is dependent on a legal framework that effectively regulates the imports of palm trees out of the affected regions. In Europe, where RPW has been responsible for massive mortality of CIDP, any palm used in a new plantation, landscape project or garden should have a valid EU Plant Passport. The movement and trade of palm trees in Europe is conditioned by the Commission Decision 2007/365/EC on emergency measures against the introduction and spread of RPW within the European Union (OJEU, 2007). This decision was modified for the last time in 2010 (OJEU, 2010) and was meanwhile incorporated into national, regional and local laws. It defines quarantine procedures by establishing demarcated infested areas and regulating import requirements and conditions for movement of palms arriving in the EU. As another example, the GCC quarantine law banned the import of palms from any region.

We have examples of successful policy implementation in Canary Islands which had been declared weevil free last in May 2016 after concerted efforts to eliminate the pest. In Mauritania, the government has acted promptly to contain an infestation in an oasis by working closely with farmers. Similarly, the benchmarks established in countries like Saudi Arabia, Morocco, Oman and Israel, should be used as guiding principles to develop a viable policy for adoption in the NENA region.

\section{A new action plan from FAO of the UN}

A new action plan that is basically an integrated approach with a variety of components to stop the spread of the red palm weevil has been endorsed at a high-level meeting at the United Nations Food and Agriculture Organization (FAO) in Rome in 2017.

Agriculture ministers and other government representatives agreed on this new strategy to fight the pest. It includes national interventions such as improved pest monitoring and greater involvement of farmers, as well as international efforts such as a proposed ban on the import of palms larger than $6 \mathrm{~cm}$ wide from infested countries. The endorsement came after scientists, pest control experts, farmer representatives and others took part in the Scientific Consultation and High-Level Meeting on Red Palm Weevil, hosted by FAO with the International Centre for Advanced Mediterranean Agronomic Studies (CIHEAM), to share the latest research and agree the best way forward.

\section{IPPC standards for protecting the palms}

Employing IPPC standards is today's mantra to deal with the invasive insect pest RPW causing global concern, more so in the NENA region, looking at its invasive spread in the North African and other Mediterranean regions. Looking at the successful policy implementation modules in the EU, such as Canary Islands using the IPPC standards, it is possible eventually to control and eradicate the pest in combination with other IMP strategies (Brunel, 2017).

IPPC has been functioning with its key role as watchdog on the movement of invasive insects and pathogens. The convention is now the global instrument for the harmonization of phytosanitary measures and it is now recognized as the only standard setting organization for plant health recognized by WTO-SPS. Developing International Standards for phytosanitary measures (ISPMs), sharing information with all stakeholders and implementing the convention in letter and spirit and developing phytosanitary capacities of the countries are the key elements for any successful pest suppression programme. As on March 2017, there are 37 standards, 12 diagnostic protocols and 21 phytosanitary treatments, all of them are now available at the click of a button on www.ippc.int. 
IPPC implemented national and global projects including legislation and policy advice in Azerbaizan, Botswana, Georgia, Moldova, Namibia, Palestine and South Sudan. Implementing the convention and developing phytosanitary capacities for NENA countries is very crucial, without which it is difficult to manage the RPW menace, leave alone the eradication of the weevil (Figure 2)

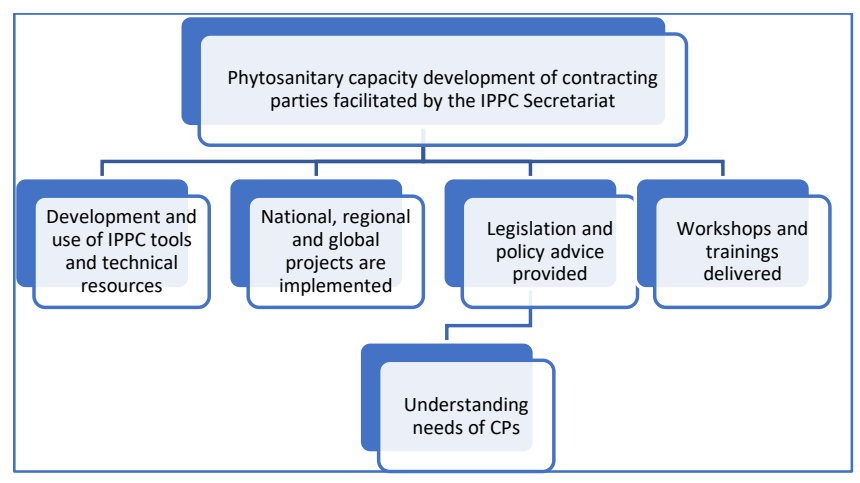

Figure 2. Organogram of objective, activities and expected outcome.

\section{الملخص}

باليجيبالي، ساراث وجو رومينو فاليرو. 2019. هل يقف عجز سياسات قضايا الحجر الزراعي في منطقة الثرق الأدنى وشمال إفريقيا وراء تفاقم

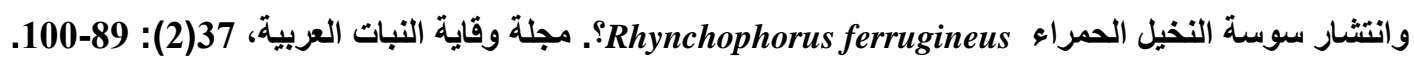

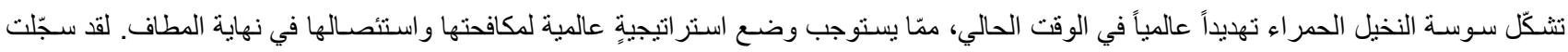

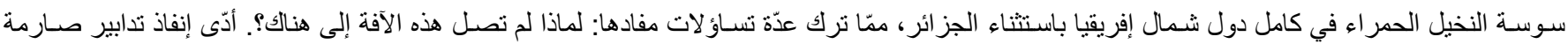
للحجر الزر اعي إلى منع دخول هذه السـوسـة إلى خمسـة بلدان من المغرب العربي (الجزائر، المغرب، تونس، ليبيا، موريتانيا) لغاية عام 2008؛ بيد أنّ المنطقة ـ

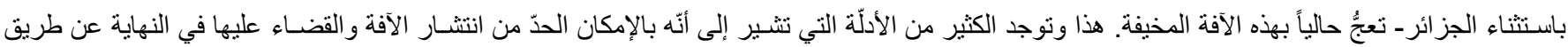

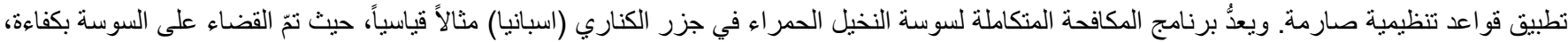

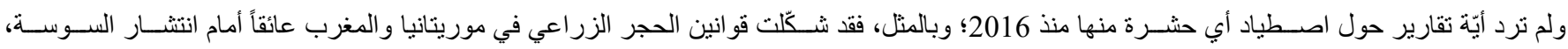
وحصرت تواجدها في بؤر الإصابة الأصلية. إنّ عدم كفاعة أنظمة الحجر الزراعي المقترنة مع ضعف إنفاذها ووجود صعوباتٍ في الكثف المبكر للأشجار المصابة قد سـاهم في الانتشـار السريع لسـوسـة النخيل الحمر اء. وتشـير تقارير قطرية تناولت جملةً متتوعةً من قضـايا صـو ابية حول الوضـع والتحديات و التوصيات بشـأن

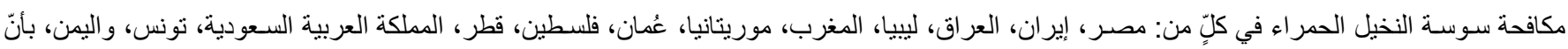

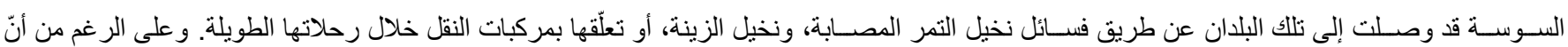
قو انين/مر اسيم/أحكام الحجر الزر اعي موجودةٌ في معظم الدول بغرض تقيد حركة المواد النباتية؛ إلاً أنّ عدم فعاليتها وضعف إنفاذها وتطبيقها قد أدى إلى الانتشـار السـريع للآفة، الأمر الذي يعزى إلى عجز في السـيانــة الحجرية. وبذلك، يجب أن نصــرف انتباهنا إلى ابتكار آلياتٍ لصــــع القرار الفعّال لتنفيذ اللوائح التنظيمية المتعلّقة بالصـحّة النباتية لوقف انتشـار سـوســة النخيل الحمر اء سـواءً داخل الحدود الوطنية أو عبر الحدود الدولية. واسـتناداً للتجارب الأخيرة في المملكة العربية السعودية، ستُعرض هنا التو صيات التي تمّت صياغتها خلال البعثة الأخيرة خلال 2018 حول بروتوكو لات الصحة النباتية والحجر الزر اعي في المملكة علّها تفيد

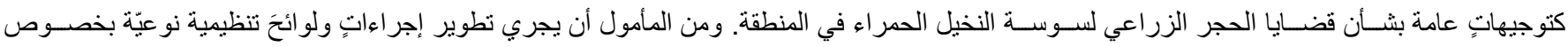

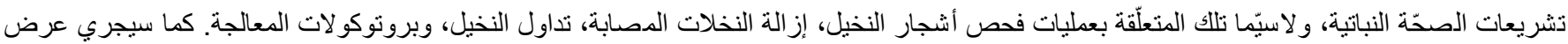
إنفاذ بروتوكو لات الحجر النباتي المتو ائمة/الموحّدة لتدابير الصحّة النباتية ومواصفات المادة النباتية المنتجة من خلال مشاتل النخيل المُعتمَدة/الموثوقة استناداً لمعايير

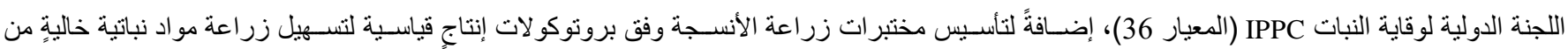

$$
\text { سوسة النخيل الحمر اء في جميع أنحاء المنطقة. }
$$

كلمات مفتاحية: Rhynchophorus ferrugineus، سوسة النخيل الحمر اء، بروتوكو لات الحجر الزراعي، الصحّة النباتبة، سياسة الأنظمة، عجز السياسات، منطقة

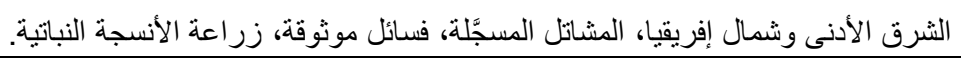

\section{References}

Abraham, V.A., M.A. Al-Shuaibi, J.R. Faleiro, R.A. Abozuhairah and P.S.P.V. Vidyasagar. 1998. An integrated management approach for red palm weevil, Rhynchophorus ferrugineus Oliv., a key pest of date palm in the Middle East. Journal of Agricultural and Marine Sciences, 3: 77-83. https://doi.org/10.24200/jams.vol3iss1pp77-83

Al-Eryan, M.A.S., I.M. El-Ghariani, A. Massry, H.A. Agleyo, S.A. Mohamed, A.A. Ikraem and S.S. Ismail. 2010. First record of the red palm weevil [Rhynchophorus ferrugineus Oliv. (Coleoptera: 
Curculionidae)] in Libya. Acta Horticulturae, 882: 413-418.

https://doi.org/10.17660/actahortic.2010.882.46

Al-Shawaf, A.M., A. Al-Shagag, M. Al-Bagshi, S. AlSaroj, S. Al-Bather, A.M. Al-Dandan, A. Ben Abdallah and J.R. Faleiro. 2013. A quarantine protocol against red palm weevil Rhynchophorus ferrugineus (Olivier) (Coleptera: Curculiondae) in date palm. Journal of Plant Protection Research, 53: 409415. https://doi.org/10.2478/jppr-2013-0061

Anonymous. 1998. Final report of the Indian Technical Team (Part A), Red palm weevil control project, Ministry of Agriculture and Water, Kingdom of Saudi Arabia. 65 pp.

Balijepalli, S.B. 2018a. A strategic component of technical cooperation programme for KSA (2017 to 2018); integrated programme for prevention and control of red palm weevil, developed and implemented in pilot area". FAO Mission Report, 56 pp.

Balijepalli, S.B. 2018b. Is policy paralysis on quarantine issues in the Near East and North Africa region leading to the buildup and spread of Red Palm Weevil? International meeting on innovative \& sustainable approaches to control the red palm weevil, 23-25 October, 2018, CIHEAM BARI, Italy, Book of Abstracts, page 10.

Barranco, P., J. De la Peña and T. Cabello. 1996. Un nuevo curculionido tropical para la fauna Europea, Rhynchophorus ferrugineus (Olivier 1790) (Coleoptera: Curculionidae). Boletin de la Asociacion Espanola de Entomologia, 20: 257-258.

Ben-Amor, R., E. Aguayo and M.D. de Miguel-Gomez. 2015. The competitive advantage of the Tunisian palm date sector in the Mediterranean region. Spanish Journal of Agricultural Research 13: e0101. https://doi.org/10.5424/sjar/2015132-6390

Bertone, C., P.S. Michalak and A. Roda. 2010. New pest response Guidelines, Red Palm Weevil (Rhynchophorus ferrugineus). Available from: http://www.aphis.usda.gov/import_export/plants/man uals/emergency/downloads/nprg-redpalmweevil.pdf

Bieńkowski A.O., M.J. Orlova-Bienkowskaja and N.N. Karpun. 2018. Plant quarantine alarm: as much as 20 new alien insect pest species including Drosophila suzukii appeared in the Caucasus in the last seven years. bioRvix.

https://doi.org/10.1101/264127

Brunel, S. 2017. How implementing the IPPC standards contributes to effective management of red palm weevil. IPPC Seminar, Stop the Red Palm Weevil, 29th March 2017.

Bouguedoura, N., M. Bennaceur, S. Babahani and S.E. Benziouche. 2015. Date Palm Status and Pespective in Algeria. 2015; 4: 125-168. In: Date Palm Genetic Resources and Utilization. Volume 1: Africa and the Americas. J.M. Al-Khayri, S.M. Jain and D.V. Jhnson (eds.). Germany: Springer.

CABI. 2018. Rhynchophorus ferrugineus (red palm weevil). https://www.cabi.org/isc/datasheet/47472
Chebbi, H. 2011. First record of Rhynchophorus ferrugineus on Phoenix canariensis in Tunisia. Tunisian Journal of Plant Protection, 6: 1-5.

Cox, M.L. 1993. Red palm weevil, Rhynchophorus ferrugineus in Egypt. FAO Plant Protection Bulletin, 41: 30-31.

El-Sabea, A.M.R., J.R. Faleiro and M.M. Abo El Saad. 2009. The threat of red palm weevil Rhynchophorus ferrugineus to date plantations of the Gulf region of the Middle East: an economic perspective. Outlook on Pest Management, 20: 131-134. https://doi.org/10.1564/20jun11

EPPO (European and Mediterranean Plant Protection Organization). November 1, 2011 www.eppo.org

EPPO (European and Mediterranean Plant Protection Organization). November 12, 2010 www.eppo.org

EPPO (European and Mediterranean Plant Protection Organization). 2015. PQR - EPPO database on quarantine pests. European and Mediterranean Plant Protection Organization, http://www.eppo.int (last accessed 1 Feb 2017).

EPPO (European and Mediterranean Plant Protection Organization). 1999. EPPO Summary of the Phytosanitary Regulations of Tunisia. European and Mediterranean Plant Protection Organization, Summaries of Phytosanitary Regulations, https://www.eppo.int/ABOUT EPPO/EPPO_MEMB ERS/phytoreg/ summaries/SUE-TN-99.doc (last accessed 1 Feb 2017)

EPPO Reporting Service. 2006. First record of Rhynchophorus ferrugineus in France and Greece and Italy, 2006/225, 226 \& 227.

EPPO Reporting Service. 2009. Rhynchophorus ferrugineus found on Howea forsteriana in Sicilia, Italy, No. 3, 2009/051.

EPPO. 2008. Data sheets on quarantine pests: Rhynchophorus ferrugineus. EPPO Bulletin, 38: 5559.

EPPO. 2014. EPPO Reporting Service, No. 2014/013. Paris, France: European and Mediterranean Plant Protection Organization.

European Commission. 2011. The insect killing our palm trees, EU eff orts to stop the RPW. Office for Official Publications of the European Communities Luxembourg.

Faleiro, J.R. 2006. A review of the issues and management of red palm weevil, Rhyncophorus ferrugineus (Coleoptera: Rhynchophoridae) in coconut and date palm during the last one hundred years. International Journal of Tropical Insect Science, 26: 135-154. https://doi.org/10.1079/IJT2006113

Faleiro, J.R., A. Ben Abdallah, M. El-Bellaj, A.M. Al Ajlan and A. Oihabi. 2012. Threat of the Red Palm Weevil, Rhynchophorus ferrugineus (Olivier) to Date Palm Plantations in North Africa. Arab Journal of Plant Protection, 2: 274-280.

Fajardo, M. 2016. The Canary Islands success story in eradicating red palm weevil Scientific Consultation and High-Level Meeting on Red Palm Weevil Management Rome, 29-31 March 2017. 
http://www.fao.org/fileadmin/templates/fcc/document s/9_PP_Moises.canary_islands_sucess.pdf

FAO. 2017. Scientific Consultation and High-Level Meeting on Red Palm Weevil Management, Rome, 29-31 March, 2017. http://www.fao.org/3/a-ms664e.pdf

FAOSTAT. 2013. Food and Agricultural Commodities Production. Available from: http://www.faostat3.fao.org/download/Q/QC/E

FA O. 2004. Global Date Production at Risk Due to Pests and Diseases: FAO Launches Global Date Palm Network. FAO., Rome, Italy.

Ganapathy, T., K. Rajamanickam, T.S. Raveendran, A.C. Lourduraj and F.J.S. Kennedy. 1992. Status of coconut cultivation in Pollachi tract. II Prevalence of pests and diseases. Indian Coconut Journal (Cochin), 23: 4-6.

Giblin-Davis, M.R., J.R. Faleiro, J.A. Jacas, J.E. Pena and P.S.P.V. Vidyasagar. 2013. Biology and management of the red palm weevil, Rhynchophorus ferrugineus. In book: Potential Invasive Pests of Agricultural Crops. J. Pena (ed.). Edition: First. Publisher: CABI, https://doi.org/10.13140/2.1.1029.1202

Karpun, N.N., E.N. Zhuravleva and E.A. Ignatova. 2014. First report about invasion of Rhynchophorus ferrugineus Oliv. on 252 Russian Black Sea coast. Fundamental and Applied Science Materials of the X Int. sci. and pract. conf. 253 Science and Education Ltd, Sheffield, 14: 85-88.

Kehat, M. 1999. Threat to date palms in occupied Palestine, Jordan and the Palestinian Authority by the red palm weevil, Rhynchophorus ferrugineus. Phytoparasitica, 27: 241-242. https://doi.org/10.1007/bf02981465

Malumphy, C. and H. Moran. 2009. Red palm weevil, Rhynchophorus ferrugineus. Plant Pest Notice, Central Science Laboratory, 50: 1-3.

Noriega, I.L., M. Halewood and I. Lapeña. 2012. The multilateral system of access and benefit sharing: Case studies on implementation in Kenya, Morocco, Philippines and Peru. Bioversity International. http://biodiversityinternational.org/

Oehlschlager, A.C. 1994. Use of pheromone baited traps in control of red palm weevil in the kingdom of Saudi
Arabia. Consultancy Report- submitted to Ministry of Agriculture, Saudi Arabia. 17 pp.

OJEU. 2007. Commission decision 2007/365/EC of 25 May 2007 on emergency measures against the introduction and spread within the community of Rhynchophorus ferrugineus (Olivier) [notified under document number C (2007) 2161]. Official Journal European Union L, 139: 24-27.

OJEU. 2010. Commission decision of 17 August 2010 amending decision 2007/365/EC on emergency measures to prevent the introduction into and the spread within the community of $R$. ferrugineus (Olivier) [notified under document number C (2010) 5640]. Official Journal European Union L, 226: 42-44.

Pelikh, K. 2009. First report of RPV from Republic of Georgia.

http://www.redpalmweevil.com/newlook/RPWReport /Georgia.html Accessed 17 October 2017

RPW Expert Team, 2017. Scientific consultation and highlevel meeting on red palm weevil management, Rome, 29-31 March 2017, 38pp.

RPW, First Report RPW in Caribbean. http://www.redpalmweevil.com/newlook/RPWReport /Caribbean.htm (Accessed on November 12, 2010).

RPW, Red Palm Weevil. http://www.redpalmweevil.com/

Rugman-Jones P.F., S. Kharrat, M.S. Hoddle and R. Stouthamer. 2017. The invasion of Tunisia by Rhynchophorus ferrugineus (Coleoptera: Curculionidae): crossing an ocean or crossing a sea? Florida Entomologist, 100: 262-265. https://doi.org/10.1653/024.100.0220

The Red Palm Weevil, A serious threat to the Portuguese landscape, 2010. http://www.aambiental.org/palmweevil/

United Nation, 2017. Red palm weevil is 'global threat' after spreading to 60 countries. https://www.reuters.com/article/us-food-palmsweevil/red-palm-weevil-is-global-threat-afterspreading-to-60-countries-u-n-idUSKBN1722MD

Zaid, A., P.F. De Wet, M. Djerbi and A. Oihabi. 2002. Chapter XII: Diseases and pests of date palm (Chapter XII). Pages 227-281. In: Date palm cultivation. A. Zaid (ed.). FAO plant production and protection paper 156, Review 1. FAO, Rome, Italy. 2002. 